\title{
Mapping the Sovereign State: \\ Technology, Authority, and Systemic Change
}

\author{
Jordan Branch
}

\begin{abstract}
This article examines the effect of cartography on the development of the modern state system. I argue that new mapping technologies in early modern Europe changed how actors thought about political space, organization, and authority, thus shaping the creation of sovereign states and international relations. In particular, mapping was fundamental to three key characteristics of the medieval-tomodern shift: the homogenization of territorial authority, the linearization of political boundaries, and the elimination of nonterritorial forms of organization. Although maps have been interpreted as epiphenomenal to political change, each of these three transformations occurred first in the representational space of maps and only subsequently in the political practices of rulers and states. Based on evidence from the history of cartographic technologies and their use by political actors, the practices and texts of international negotiations, and the practical implementation of linearly bounded territoriality by states, this article argues that changes in the representational practices of mapmaking were constitutive of the early-modern transformation of the authoritative structure of politics. This explanation of the international system's historical transformation suggests useful new directions for investigations into the possibility of fundamental political change due to the economic, social, and technological developments of globalization.
\end{abstract}

In the modern international system, both the character of states and their interactions are structured by exclusive territorial sovereignty. This foundation-with linearly bounded territorial authority functioning as the dominant principle of political organization - is unique to the modern world and was the consequence of a complex transformation in early modern Europe. The development of modern cartography was a key part of this process: new mapmaking technologies changed how actors thought about political space, political organization, and political author-

I would like to thank Christopher Ansell, Ron E. Hassner, Steven Weber, Adam Branch, Watson Branch, co-panelists at ISA and WPSA meetings, and my colleagues at UC Berkeley's Institute of International Studies. I am particularly grateful to the two anonymous referees and the editors of $I O$ for their detailed and helpful comments. 
ity. This change was fundamental to the creation of modern states and international relations, which were built around exclusive territorial sovereignty, discrete boundaries, and formal equality.

Although the ideational and material implications of cartographic technologies were not the only factors involved in the development of the state system, certain fundamental features of modern political structures can best be understood as the result of the cognitive and social impact of cartography. In particular, the treatment of political authority exclusively in terms of homogenous territorial areas separated by discrete boundary lines, which is unique to the modern state system, resulted from the development, distribution, and use of modern mapping. Because maps depicted political authority as homogenously territorial and linearly bounded even before political practices and institutions were operationalized as such, this article posits that maps reshaped actors' perceptions of the legitimate form of political authority and organization. Cartography, in short, was necessary to the transformation from medieval to modern political structures.

This transformation involved two parallel processes: a revolution in the nature of territorial authority and the disappearance of nonterritorial authorities. Together, these reorganized the authoritative basis of politics, resulting in the particular character of the modern state system. Because of changes in cartographic depictions and their use, Europeans shifted from seeing the world as a series of unique places to conceiving of the globe as a homogenous geometric surface. This shift had direct implications for how they understood political space and territorial political authority. Medieval territorial authority over a collection of locations, such as towns, was replaced by modern authority over a uniform, linearly bounded space. Simultaneously, nonterritorial authorities such as feudal bonds were undermined, eliminating the medieval variety of forms of political organization. With the increased use of maps at all levels of society in early modern Europe, forms of political authority not amenable to cartographic depiction were neglected, resulting in the uniformly territorial authority of the modern state system. This exclusively territorial definition of political authority and organization-as well as the particular, boundary-focused character of territoriality-is unique to the modern state system.

This article discusses the connection between cartographic technology and systemic political change. The empirical foundation is provided by changes in political practices driven by developments in cartographic technologies, in particular the fundamental revolution represented by the cartographic grid of latitude and longitude and the mapping of space as homogenous and linearly divisible. Theoretically, this article brings into international relations a useful body of literature on the social history of cartography, connects material technological drivers of change to processes of normative and ideational political transformation, and contributes to debates concerning the origins, character, and future trajectory of the modern state system.

The first section outlines this article's theoretical context and existing explanations of the origins of the sovereign state system. The second section draws out 
the theoretical connections between mapping technologies and political authority structures. The bulk of the article then closely examines the links between cartographic practices and political ideas and structures in early modern Europe, proposing a new understanding of this epochal transformation. The conclusion suggests implications for contemporary international political change.

\section{Authority, Sovereignty, and Political Structure}

This article contributes to several ongoing theoretical debates in international relations: the interplay between material and ideational sources of political change, the interaction between agents and the structures, and the nature of what constitutes an international system. Each is addressed in terms of the transition from medieval to modern political structures and the origins of sovereign territorial statehood.

Within the constructivist tradition, ideas, norms, and beliefs are understood to be an integral part of political structures, providing meaning to material facts and structuring practices and outcomes. ${ }^{1}$ From early critiques of neorealism ${ }^{2}$ to subsequent refinements, ${ }^{3}$ this approach to international relations has provided a framework for analyzing the origins of the sovereign state system in early modern Europe and the medieval political practices that preceded it. ${ }^{4}$ By examining the ideational effects of material cartographic technology, this article offers a useful means of studying technological drivers of change while acknowledging that the effects of such material factors are constructed by, and operate through, the ideas that give them meaning. ${ }^{5}$ In particular, my focus on techniques of representation builds on Ruggie's theorization of the role of epistemic transformation and collective imaginings in the construction of the uniquely modern form of political organization known as the sovereign state. ${ }^{6}$ Changes in representational technologies structured political interactions, but only because those technologies altered ideas about the appropriate and legitimate forms of political authority.

This historical study illustrates the complexity of the relationship between agents and structures, in which actors promulgate structural conditions and simultaneously are subject to them. ${ }^{7}$ A mutually constitutive relationship exists between representations of political space, the ideas held by actors about the organization of political authority, and actors' authoritative political practices manifesting those

1. See, in particular, Wendt 1999.

2. Ruggie 1983.

3. See Kratochwil 1989; Ruggie 1993; and Reus-Smit 1999.

4. See Kratochwil 1986; Hall and Kratochwil 1993; and Hall 1999.

5. This notion follows on Wendt's (1999, chap. 3) proposal of an ideational theory that simultaneously acknowledges the importance of material facts.

6. Ruggie 1993.

7. For example, the structuration theory of Giddens 1984. See also Wendt 1987; Doty 1997; and Wight 1999. 
ideas. Actors are constrained by the structural ideas and practices of the system but also create those constraints through their ongoing interactions. Exogenous sources of change act through this relationship: the cartographic revolution in early modern Europe created new representations that led to, first, changes in ideas of authority and, subsequently, a transformation in the structures and practices of rule. This development accords with theories of structural change that allow for the possibility of transformation in the agent-structure dynamic, such as theories of cognitive evolution ${ }^{8}$ and morphogenesis. ${ }^{9}$

This article also contributes to the theorization of international systems and efforts to delineate the character, origins, and future trajectory of modern sovereign states. ${ }^{10}$ These political structures have been seen as recurring patterns throughout history, as inventions of the late Middle Ages, or as constructs implemented only in the much more recent past. ${ }^{11}$ My focus on the connection between representational technologies and the authoritative basis of political structures builds on the constructivist approach to understanding when modern states and international relations appeared. Considering how political authority is represented, understood, and operationalized reveals the historical novelty and unique character of our sovereign state system-in particular, the exclusive reliance on territorial authority and discrete boundaries to define the highest level of political organization.

A broad literature has sought to explain the origins of modern territorial statehood and international relations, with theories generally falling into two categories: those focusing on material driving forces, such as military technology, ${ }^{12}$ organizational competition, ${ }^{13}$ property relations, ${ }^{14}$ and economic systems, ${ }^{15}$ and those relying on changes in ideas, including new representational epistemes, ${ }^{16}$ shifts in religious norms, ${ }^{17}$ and developments in political theory. ${ }^{18}$ While not denying the importance of those factors, I argue that a key constitutive driver of this transformation has been neglected, largely because existing explanations have not focused on certain key features of modern territorial statehood: the exclusively linear character of boundaries and the homogenously territorial authority claimed within those lines. Cartography's social and ideational effects provided a new framework that structured the impact of other causal processes, leading to the imple-

8. Adler 2005.

9. See Archer 1995; and Carlsnaes 1992.

10. For a variety of theorizations of international systems, see Bull 1977; Wight 1977; Waltz 1979; Ruggie 1993; Spruyt 1998; Reus-Smit 1999; Wendt 1999; and Buzan and Little 2000.

11. See, for example, Wight 1977; Waltz 1979; Gilpin 1981; Fischer 1992; Hall and Kratochwil 1993; Krasner 1993; Spruyt 1994; Hall 1999; and Osiander 2007.

12. McNeill 1982 .

13. See Tilly 1992; and Spruyt 1994.

14. See Rosenberg 1994; and Teschke 1998.

15. See Anderson 1974; and Wallerstein 1974.

16. Ruggie 1993.

17. See Philpott 2001; and Gorski 2003.

18. Skinner 1978. 
mentation of an exclusively territorial—and discretely bounded-notion of political authority and organization.

Existing explanations account for certain aspects of the modern state system but are more effective when combined with the impact of cartography. For example, Tilly's work on the competitive advantages enjoyed by larger states in terms of extraction and coercion explains why, in early modern Europe, larger and more centralized political units became dominant. ${ }^{19}$ Similarly, Spruyt points out the importance of institutional competition among diverse late-medieval actors, in which larger territorial states won out because of their efficiency advantages in several domains. ${ }^{20}$ Yet neither theory accounts for the particular form that states assumed by the early nineteenth century: exclusively territorial entities separated by discrete boundaries. Territorial organization based on authority and control over a collection of places, rather than linearly divided space, could just as easily have satisfied the need for efficient extraction and organization. Competitive pressures may have been a necessary component of this systemic transformation, but they are not a sufficient explanation for the particular form of sovereign states.

Alternatively, Ruggie's brief examination of the origins of modern statehood combines material changes, strategic incentives, and "a transformation in social epistemology ... the mental equipment that people drew upon in imagining and symbolizing forms of political community." ${ }^{21}$ While this adds the key element of how power and authority are understood-and hence instantiated in practiceRuggie's focus on single-point perspective as the representational embodiment of political change relates to the shift from multiple sources of authority to a single, centralized sovereign: "political space came to be defined as it appeared from a single fixed viewpoint." 22 This does not address another fundamental change in the nature of political organization: the homogenization of territorial authority over spaces defined and separated by discrete, linear boundaries.

Thus, I examine the role of cartography in shaping the dual transition in political authority - the transformation of territoriality and the elimination of nonterritorial authorities - that constituted the shift from medieval heteronomous complexity to modern territorially exclusive statehood. ${ }^{23}$ The undermining of medieval structures of rule combined with the new possibilities suggested by mapping resulted in sovereign territorial statehood as we know it today. This ideational effect of cartography explains why, in a period with a number of possible political structures, the particular model of the sovereign territorial state was implemented as

19. Tilly 1992.

20. Spruyt 1994.

21. Ruggie 1993, 157.

22. Ibid, 159.

23. This builds on other studies that have drawn a connection between cartography and state formation: see Biggs 1999; Neocleous 2003; Steinberg 2005; and Strandsbjerg 2008. 
the only legitimate form of rule. ${ }^{24}$ Functional efficiency alone does not explain this outcome, unique to the modern system of states. ${ }^{25}$

The fundamental character of the international system is structured by ideas and practices concerning political authority. ${ }^{26}$ For example, sovereignty is typically conceptualized in international relations as having internal and external aspects, both of which are constituted by the character of the authority that a state or ruler holds, claims, or is assigned. Additionally, the functional dimension of sovereign authority (the range of activities over which authority is claimed) can be distinguished from the constitutive dimension (the principle by which actors claim "ultimate or final authority"). ${ }^{27}$ The constitutive dimension is my focus because it differentiates the fundamental principle of sovereign authority across diverse international systems and historical periods.

I draw a distinction between spatial authorities (territoriality) and those not defined spatially (nonterritorial authorities). Within those categories, territoriality can vary in terms of how space is understood (exclusive or overlapping, center- or boundary-focused), and nonterritorial forms of authority range from personal authoritative bonds to authority over economic or social issues. ${ }^{28}$ These ideas structure the identities, interests, and behaviors of political actors because notions of what is politically appropriate or even conceivable will offer both constraints and incentives for particular actions. ${ }^{29}$ These norms constitute part of the structure of the international system - a structure that is unobservable in itself, but observable in its implications for actors' ideas and practices.

In early-nineteenth-century Europe, rule came to be defined exclusively in terms of territories with boundaries between homogenous spatial authority claims. My argument challenges theories that have pushed sovereign statehood back much further, seeing key aspects of sovereignty in the late Middle Ages, ${ }^{30}$ in the sixteenth century, ${ }^{31}$ or after the Westphalian settlement. ${ }^{32}$ These studies point toward the origins of certain aspects of statehood but do not explain the modern system's exclusive reliance on territorial authority and linear boundaries to define states. Defined broadly, states and state systems may have existed during many historical

24. European colonial empires diverged from the model of sovereign states but-as will be discussed below-were built on a similar foundation of exclusively territorial authority defined by linear boundaries.

25. Contrary to Krasner's argument that territorial rule can be explained solely as a practical, logicof-consequences choice by rulers from a repertoire of acceptable principles. See Krasner 1993.

26. The basis of sovereignty and international structure in political authority is noted by, among others, Lake 2003 and 2009; Milner 1991; and Thomson 1994.

27. Thomson 1994, 14-15.

28. The variety within territorial and nonterritorial forms of authority is illustrated below, with regards to early modern Europe. For the concepts in general, see Sahlins 1989; Ruggie 1993; Kratochwil 1986; and Sack 1986.

29. March and Olsen 1998.

30. Strayer 1970.

31. See Wight 1977; and Skinner 1978.

32. Philpott 2001 (among many others). 
periods, including sixteenth- and seventeenth-century Europe. ${ }^{33}$ Yet on the key dimension of how political authorities are defined, claimed, and separated, modern territorial statehood is distinct and a historically recent arrival.

\section{Cartography and Political Authority: Theoretical and Methodological Considerations}

The political authorities that constitute the international system are structured by a number of factors, including the understanding of space in representations such as maps. My approach to the social and political effects of mapmaking grows out of historical and theoretical literature on the interrelations among maps, their producers, their consumers, and their social context. ${ }^{34}$ These theories offer a useful foundation for understanding the cartographic construction of modern state sovereignty. In short, maps and mapmaking are never value-neutral scientific practices.

Contrary to the conventional distinction between scientific maps (as good) and propaganda maps (as bad), all maps elide certain aspects of the world and construct a particular representation through what they depict. Thus all maps can be examined in terms of what they include and exclude, what is emphasized or elided, and how social relations or understandings enter into map creation and map reading. Besides conscious decisions to leave off classified or embarrassing information, elisions and distortions are often produced unintentionally, shaped by mapmaking practices and the unconscious prejudices or understandings of the mapmakers and their social context. ${ }^{35}$ Moreover, the relationship between what is considered important and what is mapped goes both ways: the use of maps depicting certain spaces or features further emphasizes the normative importance of those elements.

In terms of the transformation of European authority structures, the early modern cartographic revolution was fundamental to the construction of modern states built on territorial exclusivity. Without the production and extensive use of Ptolemaic mapping, three key features of modern political authority would likely be absent: the homogeneity of territory as a geometrically measured space, the purely linear character of political boundaries, and the elimination of nonterritorial authorities. The resulting dominance of boundary-defined territorial authority is a unique feature of modern statehood. Furthermore, cartographers did not set out to reshape ideas of political authority. Maps had particular characteristics-the coordinate grid, linear spatial divisions, homogenous territorial coloring — not due to explicit demands for such maps by rulers interested in promoting a particular political vision,

33. Buzan and Little 2000.

34. Including, among others, Brotton 1997; Cosgrove 2001; Harley 2001; King 1996; Klinghoffer 2006; Pickles 2004; and Wood 1992.

35. Harley 2001, chaps. 2-3. 
but instead due to a commercial market for printed objects. Political actors then used these objects as a means of understanding their world.

The impact of map use involved a long-term change in normative structures and mentalities, not a sudden transformation of an individual actor's point of view. These changes occurred through generational turnover and socialization, as political advisors and decision makers were educated in an increasingly map-filled environment. ${ }^{36}$ Maps became one of the primary means of understanding the world and its political structures: "Cartographic reason seems to have been so powerful a force in the sixteenth and seventeenth centuries that it came to signify the most important forms of reason. To map was to think." 37 Such changes in basic cognitive frameworks are slow and unintended and may have effects far beyond what actors themselves are aware of.

This cognitive impact of mapping has implications for how one studies its political effects. Technological changes are directly observable, as are transformations of material political practices. Yet ideas about political authority and organization are not directly observable, particularly when changes are intergenerational, as individual actors might not note in journals or letters that their thinking has changed. I argue that certain representational technologies (namely, maps) structure the basic understandings that actors have about their world without their being directly aware of either the cause or even the effect: what actors consider normal or even imaginable is structured without their conscious knowledge. ${ }^{38}$

Methodologically, the best means of documenting changes in ideational frameworks is to study their observable implications or effects. ${ }^{39}$ Thus, using historical narrative analysis, ${ }^{40}$ I examine changes in practices, both cartographic and political, and theorize an explanation that accounts for the changes I observe. ${ }^{41}$ New mapping technologies put new representations and new tools into the hands of political actors; the effects of cartographic practices on rulers and decision makers are then observable in subsequent changes in their political goals and practices. As actors altered their ideas about the appropriate or possible definition of political authority, one can observe them pursuing new interests built on those new ideas.

One means of entering this causal chain at the level of ideas is to examine political documents such as peace treaties. These expose the mental framework of political interaction, since the character of what is offered or claimed in treaties reveals not just the particular interests of actors but also the nature of what they are arguing over, and thus how they conceive of political authority and organization. ${ }^{42}$ Observable changes in treaty texts fit between new mapping practices and trans-

36. Buisseret 1992 .

37. Pickles 2004, 77. See also Mukerji 2006; and Brotton 1997.

38. See Harley 2001; and Wood 1992.

39. Wendt 1987.

40. Mahoney 1999.

41. For a similar approach, see Thomson 1994, 5.

42. Krasner 2001, 34. 
formed material political practices, establishing a causal connection from cartographic practices through ideas to political practices and outcomes. Studying this intersection between technological change, political ideas, and the material practices of rule provides a new lens through which to understand both this epochal political transformation and the interplay between material and ideational change more generally.

\section{Early Modern Cartography and State Formation}

In order to demonstrate the role of mapping in the shift from medieval heteronomy to modern statehood, the next five sections examine the following: medieval mapping techniques and political structures, the Renaissance cartographic revolution, the political effects of this technological change, early modern France as a representative case, and the unique character of European cartography and political structures.

\section{Medieval Cartography and Political Authority}

The mutually constitutive relationship between maps and political authority is illustrated by medieval European cartographic and political practices. Political organization and interactions in late medieval Europe were structured by a complex mix of authority types, involving both territorial and nonterritorial authorities in overlapping, decentralized arrangements. Territory, furthermore, was understood very differently from today: medieval actors claimed authority over collections of places rather than geometrically defined spaces, with centers of strong authority weakening outward into unclear zonal frontiers. Nonterritorial authorities were common, including the personal bonds of feudal ties, oaths of allegiance between monarchs and subjects, and authorities over economic or religious issues. This complex mix of authority types involved significant overlaps, both of territorial control (shared authority, territorial enclaves, and unclear zonal frontiers) and of nonterritorial forms such as multiple homage in feudalism. Consequently, political interactions involved a wide variety of actors and organizations, including city-states, monarchies, the papacy, corporate groups, and city-leagues. The relations among actors incorporated a complex mix of hierarchical and anarchical forms, making the modern division between internal and external politics unclear or inconceivable within Christendom. ${ }^{43}$

Medieval mapping both illustrated and shaped these ideas about political authority. Mappae mundi, for instance, were large world maps that schematically depicted the three continents of the Old World and contained images and text representing

43. See Bloch 1961; Fischer 1992; Ganshof 1970; Hall and Kratochwil 1993; Holzgrefe 1989; Mitteis 1975; Osiander 2007; Ruggie 1993; Sahlins 1989; and Spruyt 1994. 
and describing religious and historical places and events (Figure 1). These not only distorted geography (to our eyes) but also emphasized the importance of places such as cities over the spaces in between them. ${ }^{44}$ Other types of maps were used for travel, on land with itinerary maps and by sea with portolan charts (Figures 2 and 3). Itinerary maps visually schematized the idea of the world as a series of places-such maps showed only the places along routes, with no effort to depict accurate geographic relationships. Portolan charts, though intended for navigation in the Mediterranean and dominated by compass bearings and coastal landmarks, often included one element of political information: flags bearing a ruler's coat of arms placed on towns. ${ }^{45}$ The form of territoriality represented —and reinforced—by point indicators such as flags involves a claim radiating outward from a center. Other representational forms, such as bird's eye views of cities, similarly reflected a focus on centers rather than boundaries. ${ }^{46}$

These maps both depicted and reinforced medieval political ideas. Medieval kingdoms, though lacking a single center, were nonetheless understood-and represented-as collections of centers, rather than bounded territories. Terrestrial maps, by not depicting linear boundaries between political units, reflected the absence of such divisions on the ground. None of these mapping traditions was built on the geometric foundation that all modern maps incorporate: the latitudelongitude grid.

Maps were exceedingly rare in the Middle Ages, mainly because they were expensive, hand-drawn manuscripts. Many of the purposes that maps are used for today, such as property ownership or travel directions, were fulfilled instead by texts. ${ }^{47}$ Thus nonterritorial forms of authority were both made legitimate by and represented in these written texts, which-unlike maps-have no inherent bias toward spatial forms of authority; personal or jurisdictional authorities could be catalogued alongside lists of places. In the Treaty of Verdun (843 A.D.), for example, Charlemagne's empire was divided based on an exhaustive listing of jurisdictional rights, offices, and revenues, not on delimited territories. ${ }^{48}$

These connections between mapping and understandings of political space were mutually reinforcing because users and creators of maps shared a single set of spatial assumptions and operationalized them in both cartographic and political practices. It would take a change in mapping technology, exogenous to political concerns, to shift the relationship from mutual reinforcement to transformation, as Renaissance mapping techniques would create new maps that undermined medieval notions of space and suggested a new, geometrically derived ideal of exclusively territorial political authority.

44. On mappae mundi and medieval regional mapping, see Cosgrove 2001; Edson 1997; and Harley and Woodward 1987, chaps. 17-20.

45. Campbell 1987.

46. Schulz 1987.

47. See Grafton 1992; Woodward 2007, chap. 2; and Revel 1991.

48. Ganshof 1970, 48. 


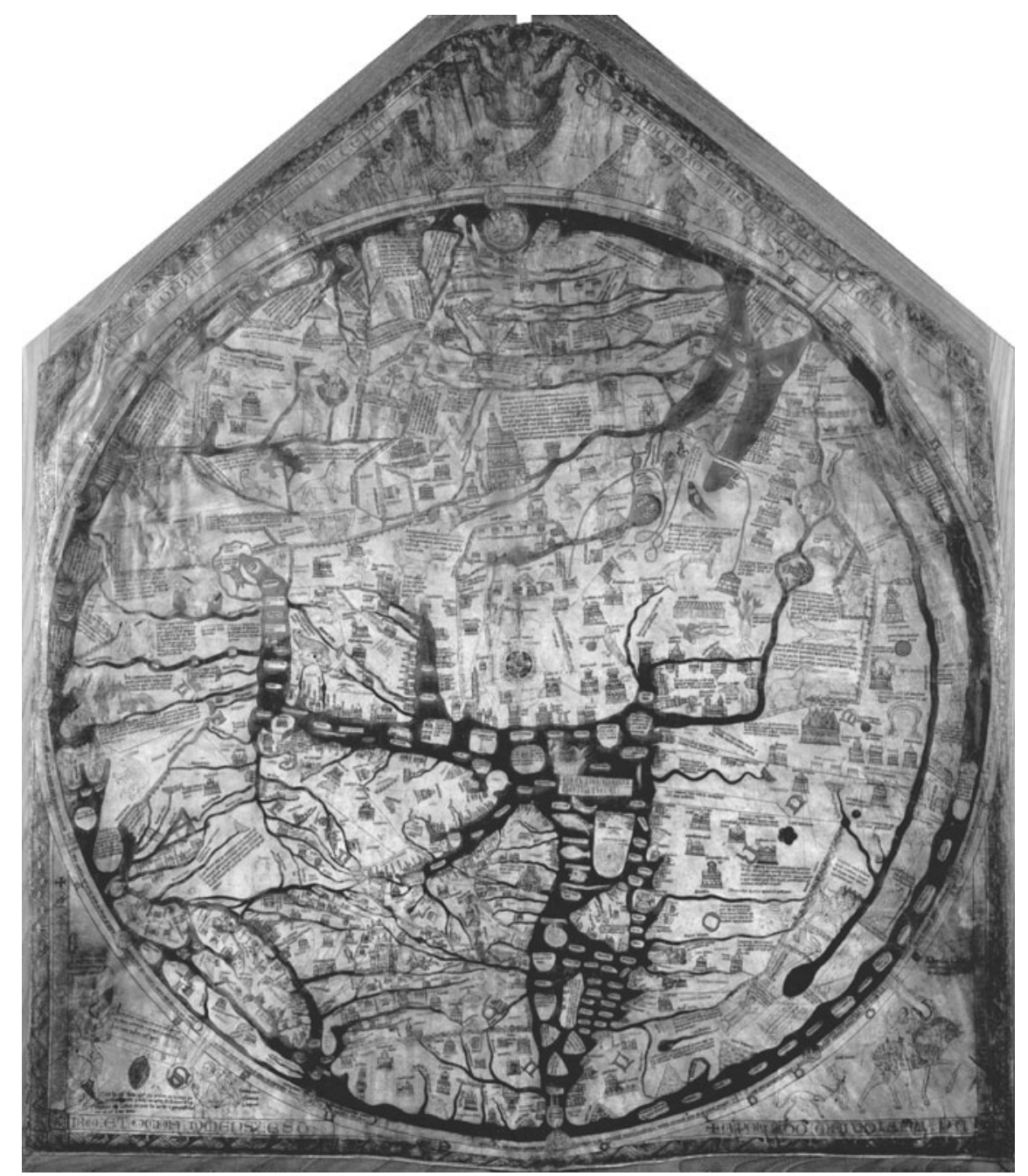

Note: As with many mappae mundi, this map depicts Europe, Asia, and Africa, with east at the top and Jerusalem in the center.

Source: Reproduced with the permission of the Dean and Chapter of Hereford Cathedral and the Mappa Mundi Trustees.

FIGURE 1. Hereford Cathedral Mappa Mundi, circa 1290 A.D.

\section{The Cartographic Revolution of the Renaissance}

Modern cartography can be traced back to the fifteenth-century transformation of techniques of map creation, production, and distribution that began with the trans- 


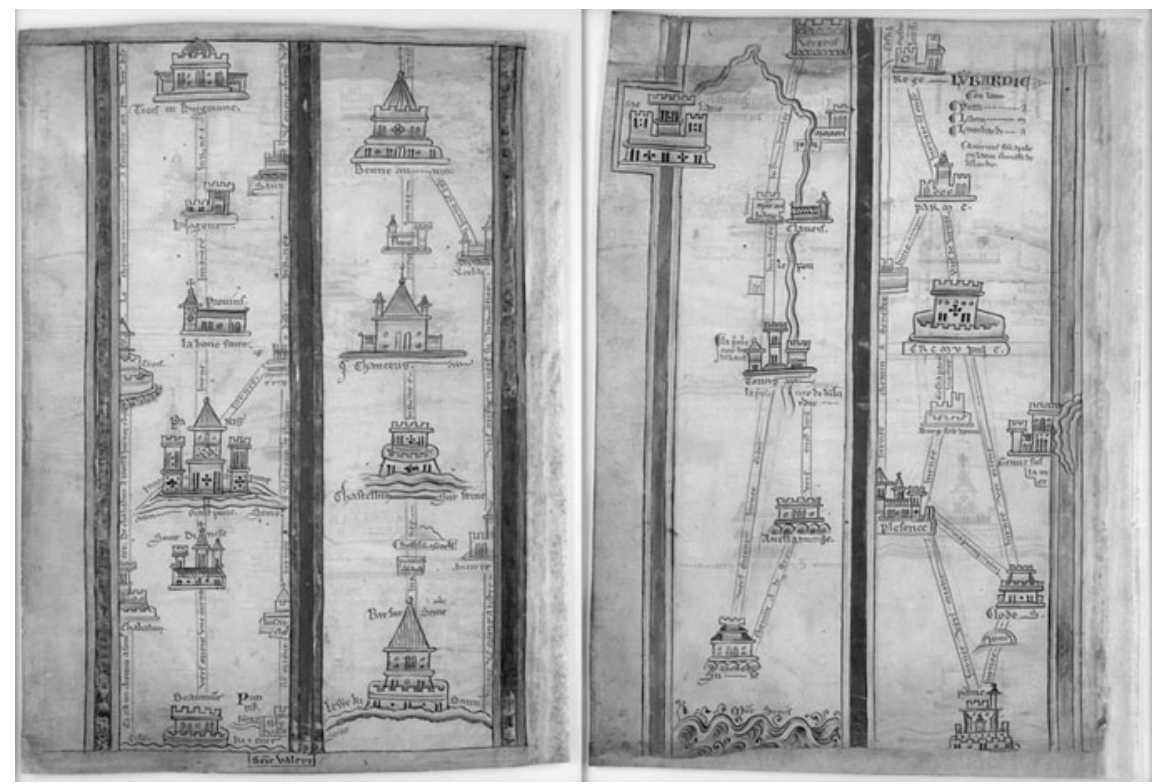

Note: These are two pages from an itinerary of the route from London to Jerusalem. On the left is southern England and northern France, on the right is northern Italy.

Source: Courtesy of the British Library. Copyright British Library Board (Royal MS 14 C.vii)

FIGURE 2. Medieval itinerary map, Matthew Paris, 1255 A.D.

lation of Ptolemy's Geography into Latin. In addition to geographic information, this classical Greek work contained instructions for basing maps on the coordinate grid of latitude and longitude. This celestial coordinate grid (or graticule) has served as the foundation for mapmaking ever since. Compare, for instance, a medieval mappa mundi (Figure 1) against world maps from the fifteenth and sixteenth centuries, which use the graticule (Figure 4). The latter project the earth onto the grid, however inaccurately, while the mappa mundi differs in form as well as content from world maps today. Subsequent centuries' developments in projection methods, position-finding, and surveying all incorporate the basic principle of Ptolemaic mapping: a grid system based on celestial coordinate position, with a geometric correlation between the earth's surface and the map. Combining with this qualitative shift toward the use of the Ptolemaic grid was the quantitative explosion in map production due to the printing press: from "a few thousand maps in circulation" before 1470 to "millions" in the sixteenth century, ${ }^{49}$ exposing Europeans to

49. Woodward 2007, 11; see also Karrow 2007. On the "communication revolution" due to printing, see Eisenstein 1979. 
the new visual language of Ptolemaic cartography in maps and atlases varying from expensive decorative works to cheaper small-format products. ${ }^{50}$

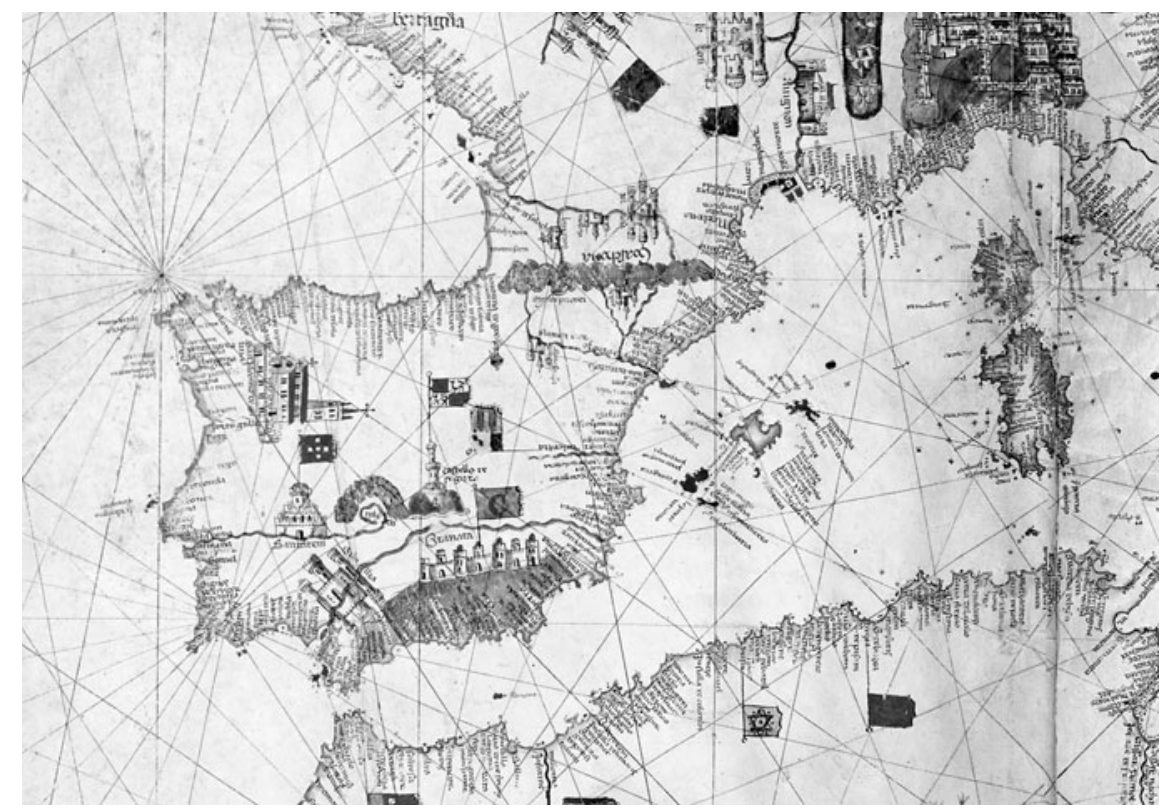

Source: Courtesy of the James Ford Bell Library, University of Minnesota.

FIGURE 3. Portolan chart, Albino de Canepa, 1489 (detail)

During the late-sixteenth and early-seventeenth centuries, governmental cartography began to follow ongoing private mapping efforts, reflecting rulers' growing interest in cartography.$^{51}$ In the sixteenth century, rulers simply collected existing privately published maps, following recommendations from political authors such as Niccolò Machiavelli. ${ }^{52}$ Around 1600, rulers became more active cartographic consumers, primarily by paying cartographers to collate existing maps. Many government mapping projects, however, did not immediately embrace the latest practices. Even in the late sixteenth century, publicly displayed mural map cycles were often collections of images of cities, similar to medieval bird's-eye views, rather than Ptolemaic grid-based maps. ${ }^{53}$

50. Mukerji 2006.

51. See Buisseret 1992; and Woodward 2007, chaps. 26-62.

52. Harley 2001, 57.

53. See, on Italian map cycles, Schulz 1987; on Spanish King Philip II's similar mapping project, see Mundy 1996. 
The unsatisfactory character of maps based on existing works-suffering from poor sources and a lack of precision-later led to governments' commissioning their own maps. But governments began to sponsor surveys of their realms only in the late seventeenth century, aiming to produce up-to-date, accurate, and possibly secret maps. ${ }^{54}$ These projects trailed, by a century or more, the production of grid-based maps by commercial printers. The relatively late governmental adoption of geometric mapmaking reveals the nonpolitical motivations behind the initial shift in representational techniques - techniques that nonetheless had political effects.

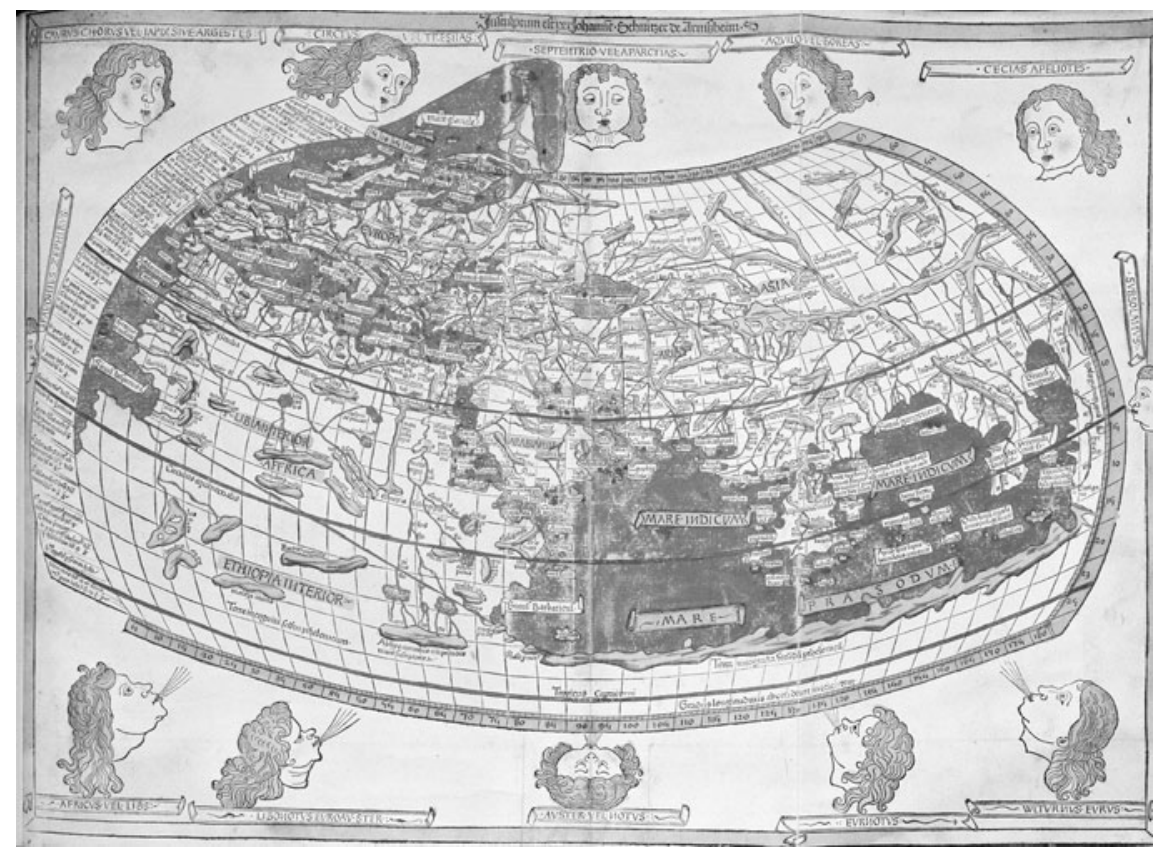

Source: Courtesy of the British Library. Copyright British Library Board (IC. 9304).

FIGURE 4. World map from Claudius Ptolemy's Cosmographia, 1482

\section{Cartography and the Restructuring of Political Authority}

Contrary to the medieval differentiation of places, the coordinate grid of latitude and longitude provides an abstract foundation for modern mapping, yielding a geometric understanding of space and political territory. ${ }^{55}$ Although mapmakers rep-

54. Konvitz 1987.

55. See Brotton 1997; Lefebvre 1991; and Sack 1986. 
resented a world filled with homogenous, linearly bounded territories by the early seventeenth century, political ideas changed to reflect this new and distinct understanding of political authority and organization only in the eighteenth century. Political practices then implemented linear territoriality in the late eighteenth century and after.

While politics in the late Middle Ages involved the coexistence of territorial and nonterritorial political authorities, the modern international system is uniquely structured by the exclusive use of territoriality to define political organization. The massive increase in the production and use of Ptolemaic maps in Europe helped delegitimate nonterritorial authorities. As people came to envision the world increasingly in terms of these maps, ideas about political authority that were not depicted in them-or that could not be depicted in them-lost their normative basis and were negated and eliminated as acceptable foundations for political authority. This ideational change shaped the impact of incentives favoring centralization and bureaucratization, including military and organizational competition, leading to the uniformly territorial — and boundary-defined-form of modern sovereign statehood.

Mapping according to Ptolemy's graticule uses a uniform spatial scale that geometrically correlates the earth's surface with the map. This means that "each point on the map is, in theory at least, accorded identical importance, thus reducing the power of the center." ${ }^{56}$ Unlike medieval cartography, Ptolemaic mapping can be centered anywhere and, thus, is effectively centered nowhere. The world is no longer portrayed as a collection of differentiated places but instead as a homogenous surface on which points are located in geometric terms. This had political implications: authority claims shifted from particular centers or differentiated places to homogenously understood spaces. The medieval notion of authority as strong at centers of control and weak in peripheries was replaced by an emphasis on clear and distinct boundaries between political spaces. Practically, this involved transforming ambiguous, zonal, enclave-ridden frontiers into linear boundaries.

While it may not be impossible to map complex territorialities or nonterritorial authorities, early modern cartographers simply did not do so. Their response to the complexity of early modern authority structures was shaped by their mapping techniques-based on Ptolemy's graticule and the resulting geometric representation of space-which drove them to simplify overlapping authorities and to depict all political structures as territorial.

The connection between mapping space as homogenous and geometric and claiming political authority as such is complicated. On the one hand, a cartographer who understands space as geometrically homogenous may operationalize that view in maps by filling in delimited areas with solid colors. But the connection between depictions in maps and the homogeneity of space could also work in the other direction if readers who consistently make use of maps with color-filled areas neatly separated by linear boundaries are influenced by this depiction, constituting and 
reinforcing a view of the world as a collection of homogenous and linearly defined entities. ${ }^{57}$ This mutual dynamic is evident in the way maps are created and read today: the globe filled with color-coded and linearly bounded political entities both results from our predominant understanding of the world (as filled with territorial states) and reinforces that understanding. ${ }^{58}$

Early modern cartographers drew maps filled with uniform, linearly bounded territories before similar political ideas or practices appeared. These representational changes reshaped the constitutive foundations of political actors' identitieswhat authority is claimed over-leading to changes in actors' interests and therefore behaviors. Maps, created for nonpolitical motives, preceded political ideas and practices in terms of territorialization. Changes in mapmaking were not the consequence of political transformations.

Beginning with mass printing in the sixteenth century, linear boundaries were increasingly drawn on maps, with color added by hand after printing. By the middle of the seventeenth century, nearly all atlas maps had boundary lines. ${ }^{59}$ While this might be interpreted as a case of maps representing progressively linear and territorial boundaries between centralizing states, the boundaries depicted on these increasingly detailed maps did not reflect the actual political practices on the ground, or even the theoretical ways in which contemporary rulers claimed political authority.

For example, the frontiers of states such as France or Spain were rarely linear on the ground and involved extensive overlaps, enclaves, and nonterritorial complexities across broad frontier zones, through at least the late eighteenth century. ${ }^{60}$ Yet maps depicted a continent filled with discrete boundaries between territories, including units that had no unified political structures whatsoever, such as Italy and Germany (see Figure 5). This does not mean that no actors conceived of their rule in a territorial fashion, or even that no boundaries were operationalized linearly. It does illustrate, however, that the distinctly modern notion of political authority as defined exclusively in terms of territory-and territory defined exclusively by linear divisions_-did not take hold until the late eighteenth century and after. However, the discrete boundaries between homogenous territories in maps anticipated the linear form that authority would take in later centuries if not the exact divisions and units.

During the sixteenth and seventeenth centuries, territory was described in peace treaties as lists of places, not as linearly divided spaces. In 1648, for example, the Treaty of Münster (Westphalia) used no cartographic language and made no mention of maps for reference or for the demarcation of boundaries. ${ }^{61}$ Instead,

57. This process reflects theories of learning that incorporate changes in fundamental ideas and practices, not just the assimilation of new informational knowledge. For example, Adler 2005, chap. 1.

58. See Taylor 1995; and Brenner 1999.

59. Akerman 1995, 141; see also Ehrensvärd 1987; and Koeman 1970.

60. See Sahlins 1989 and 1990; and Osiander 1994 and 2007.

61. While the foundational status of Westphalia has been questioned by recent studies (including, most effectively, by Osiander 2001), it remains a popular narrative both inside and outside of inter- 
after naming a place such as a town, the treaty listed an exhaustive collection of subjurisdictions, economic resources, and other associated rights or privilegesterritorial and nonterritorial —all of which had to be explicitly named to be included. ${ }^{62}$ This complex, text-based allocation of political authorities persisted even while maps were filled with linear boundaries and color-filled spaces, suggesting that mapmakers were not mapping either existing political arrangements or the ideas held by rulers concerning the nature of their authority.

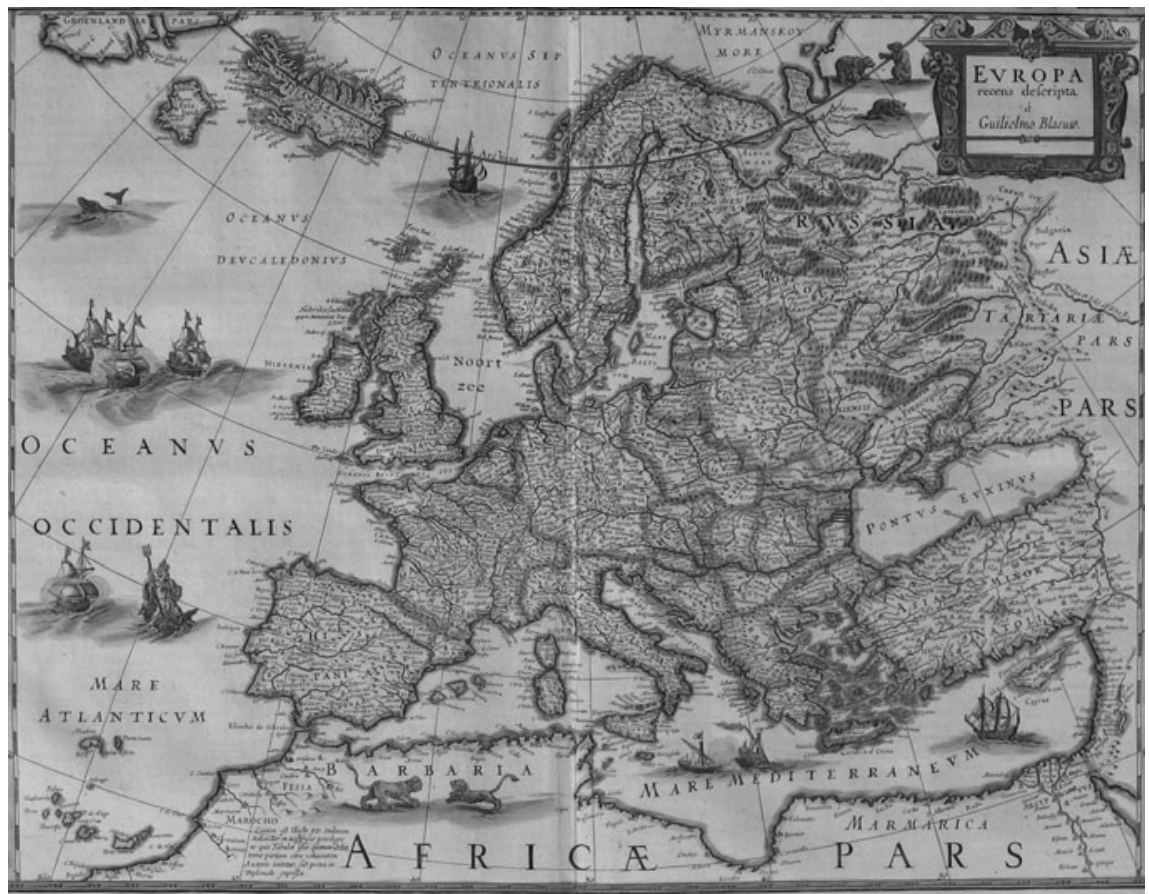

Note: This map is from the Latin edition of Joan Blaeu's Theatrum Orbis Terrarum. Source: Courtesy of Hemispheres Antique Maps (betzmaps.com).

FIGURE 5. Map of Europe, Willem Blaeu, published circa 1644-55

In the eighteenth century, the transition began to the distinct form of territoriality that characterizes modern states and the state system: territory defined exclusively by linear boundaries and held equally over all space within those lines. This

national relations. For illustrative listings of the prevalence of the "Westphalian myth," see Krasner 1993, 239; and Osiander 2001, 260-61.

62. Treaty text in Israel 1967. 
transformation occurred first in ideas and only later in practices. Writing in the mid-1700s, Emerich de Vattel and Christian Wolff were "among the first theorists of international law to identify territorial boundaries as the point at which sovereignty found expression." 63 Only in this period did the idea of political authority as defined exclusively by territories with linear boundaries begin to take hold as a structuring concept for political organization and interaction. International discussions and negotiations were increasingly framed in cartographic terms and they increasingly used cartographic tools; complex medieval authority structures were simply no longer part of the political conversation.

This trend toward territorialization culminated in the post-Napoleonic negotiations and treaties of 1814-15: these texts contain extensive descriptions of boundaries, drawn as lines, discussed in terms of maps (when they existed) or surveying and map creation (when they did not), and delimiting territories to be held "in full sovereignty and property" within those lines. ${ }^{64}$ This drive toward exclusivity allowed for no overlap or ambiguity. Linear divisions were accompanied by passages actively removing nonterritorial authorities:

His Majesty the King of Prussia and His Majesty the King of Saxony ... renounce, each on his own part, and reciprocally in favor of one another, all feudal rights or pretensions which they might exercise or might have exercised beyond the frontiers fixed by the present Treaty. ${ }^{65}$

The linear boundaries so carefully drawn in the treaty text-and to be inscribed on maps-were used to eliminate nonterritorial authorities. Although particular boundaries had been negotiated as linear divisions before, only with this settlement was the exclusively geometric understanding of territory applied to the European state system as a whole.

Following this shift in ideas, political actors began to put into practice the notion that authority is defined exclusively by homogenous territoriality and linear boundaries. Thus by the late eighteenth and early nineteenth centuries, political rule was territorialized by the impact of mapping: boundaries were made linear, internal rule was made homogenous, and nonterritorial authorities were eliminated. The shift to the modern states system, therefore, involved more than the disappearance of many European political units; ${ }^{66}$ surviving polities also underwent fundamental changes in political structure.

The uniformly territorial basis for political organization extended into European overseas expansion as well: although the hierarchical organization of colonial empires diverged from the anarchical relations among European states, colonial possessions were nonetheless defined in similarly territorial terms, as homog-

63. Sahlins 1989, 93.

64. For example, Vienna treaty of 1815, Article II; in Israel 1967, 520.

65. Vienna treaty of 1815, Article XIX; ibid., 527.

66. Noted by Tilly 1992; Spruyt 1994 and others. 
enous spatial entities separated by linear boundaries ${ }^{67}$ In fact, Europeans made political claims based on cartographic territoriality earlier in the Americas than within Europe. Beginning with the 1494 Treaty of Tordesillas between Spain and Portugal and continuing in subsequent centuries, European powers claimed colonial territories as homogenous spaces with linear divisions. ${ }^{68}$ The unquestionable divergence between hierarchy within empires and anarchy among sovereign states does not contradict the effect of mapping; instead, this difference is a variation within the framework of exclusive territoriality constituted by the characteristics of early modern cartography. Therefore, in spite of the fact that imperial political structures differed qualitatively from sovereign states, the authoritative foundation of both these contemporary forms of organization resulted from the ideational impact of early modern mapping.

\section{Cartographic Statehood as an Unintended Outcome}

States in the seventeenth century, though more centralized and territorial than medieval polities, were not exclusively defined by linear boundaries. At the Congress of Vienna, on the other hand, all actors were defined in terms of exclusive territorial authority, and complex heteronomies were replaced by an anarchical system managed by the great powers. In this period, the modern nature of sovereign statehood becomes clear: authority is solely territorial, exclusive, and centralized. Thus, after 1815 the only recognized international political actors in Europe were territorial states, with theoretically exclusive and complete authority within their boundaries. ${ }^{69}$ Sovereign territorial statehood was finally consolidated when this new international system was constructed out of the ruins of Napoleonic Europe.

The relative timing of these changes indicates that the map-based understanding of political authority as exclusively territorial was not epiphenomenal but rather preceded and shaped the transformation of political rule on the ground. In the nineteenth century, political practices finally caught up to depictions in maps. This historical sequence raises the question of why sixteenth- and seventeenth-century mapmakers would depict bounded territorial units that did not exist at the time. The inconsistency and anachronistic nature of many boundaries on maps suggest that cartographers might not have meant to show political units. ${ }^{70}$ Yet there is evidence to the contrary: for example, one seventeenth-century atlas states that maps help

67. See Bassett 1994; Brotton 1997; Edgerton 1987; Pickles 2004; and Sack 1986.

68. Due to the fact that Europeans did not recognize any pre-existing non-European authorities as legitimate, the most effective means of making claims from afar was to use the newly available tools of cartography and the concomitant geometric form of territorial authority. This is evident in SpanishPortuguese treaties, in England's North American colonial charters, and in nineteenth-century imperialism in Africa. For a full exploration of the nature of colonial territoriality and the relationship between colonial ideas and practices and those applied within Europe, see Branch 2009.

69. See Osiander 1994; and Schroeder 1994.

70. See Akerman 1984; and Biggs 1999, 393. 
readers "to know about the political State."71 It was the medium of commercially printed Ptolemaic mapping and mapmakers' related worldview that drove this depiction of the world as a collection of homogenous, linearly bounded territories.

The geometric foundation of modern cartography implicitly encourages the use of lines and homogenous areas to differentiate spaces. ${ }^{72}$ While finding an accurate way to depict medieval forms of authority (over a series of places or persons, potentially overlapping and shared) was a challenging task, drawing a linear boundary was relatively simple. Coloring in those delineated spaces provided an easy way to differentiate areas visually. This cartographic imperative toward simplification and territorialization of complex authorities also structured other drivers of political change. For example, Claude de Chastillon was sent in 1608 by the French crown to survey a complex frontier ${ }^{73}$ when increasing military costs were driving all European rulers to attempt to tax more efficiently. ${ }^{74}$ Improving taxation required improving rulers' knowledge of their realms; thanks to the previous century's explosion in map production and use, cartography provided one of the most readily available means to gather and manage this information. ${ }^{75}$

Although Chastillon reported back to the crown with both a written description and maps, his criteria for delineating the frontier included predominantly nonterritorial notions, such as feudal allegiance, taxes owed, and judicial decision making. Comparing text with map reveals the inherent need for cartographic simplification:

The château of Passavant, [Chastillon] says, belongs to Lorraine, though the town and wood are French. Baffled by the problem of distinguishing between these areas, our cartographer has drawn a little enclave, with a château in the south of it. At Martinvelle, three-quarters of a league from Passavant, all the hearths owe tax to the king of France; this village, according to Chastillon, was partially French and partially lorrain. On our map it is shown as lying in Lorraine. $^{76}$

The complex authorities on this frontier had to be simplified to draw a readable map, converting nonterritorial links to an image of territorial authority, defined by linear boundaries. The tendency of Ptolemaic cartography toward simplification and territorialization of political relations is illustrated in conversions such as these, performed whenever a map depicted complex authority structures as linearly territorial. The newly developed mapping techniques and ideas thus redefined how rulers centralized and improved their extractive efforts, driving the eventual consolidation of cartographically defined territorial statehood.

71. Quoted in Pelletier 1998, 45.

72. Harley 2001.

73. Buisseret 1984 .

74. Tilly 1992.

75. Konvitz 1987.

76. Buisseret 1984, 78. While Chastillon's maps are lost, contemporary maps of this frontier were likely based on Chastillon's surveying and illustrate the same process. 
The implicit tendency of grid-based mapping to depict a world filled with linearly bounded spaces was also supported by commercial motivations. Color-filled maps directly served the interests of mapmakers, since adding color after printing was an easy way to add value to maps. In early modern Europe, aesthetic appeal was one of the primary considerations among map consumers, particularly rich elites. ${ }^{77}$ Even in the eighteenth century, the accurate cartography of Enlightenment projects, such as the Cassini survey of France, was still overshadowed by the continuing emphasis on maps as beautiful objects, and a large part of their appeal was in the coloring. ${ }^{78}$

Mapmakers did not consciously aim to promote the understanding of political space as exclusively geometric; their depictions were instead shaped by the principles of grid-based cartography. By competing with each other for the attention of wealthy patrons and relying on geometric mapping practices, mapmakers habitually used linear boundaries and color-filled spaces and unintentionally encouraged a particular conception of territorial authority. The maps they created were easily read as depicting a world of homogenously territorial states.

In short, cartography's effect on ideas of political authority was in part a byproduct of market demands for maps in the early modern period. This effect was unintended-no agency was directing this process and no constituency was clamoring for change. Although there ended up being actors who benefited from the shift to exclusive territoriality and linear boundaries-namely, those centralizing rulers capable of harnessing cartography and territoriality to their purposes - this change was not a case of actors intentionally promoting a new way of seeing the world. ${ }^{79}$ Rather, due to the use of maps throughout society, a shift occurred in ideas about which forms of political authority were appropriate and which were not. Although mapmakers almost certainly did not set out to change the minds of their customers, their maps implicitly represented the mapmaker's worldview and advocated it with map readers. ${ }^{80}$

This transformation in ideas about political organization is not just about actors using a new tool to pursue their goals, such as security or aggrandizement. Instead cartography made certain goals imaginable and appealing. In the eighteenth and nineteenth centuries, the increasingly territorial and linear state identity yielded a new set of interests, based around notions of territorial exclusivity, continuity, and security. ${ }^{81}$ As actors came to think of authority in exclusively territorial terms, they also found that pursuing goals based on those conceptions could be politically useful. Thus, rulers driven toward centralization by other factors were able to use territorial exclusivity both to construct the "mutual recognition game" of

77. See Ehrensvärd 1987; and Koeman 1970, 32.

78. Pedley 1992.

79. Unlike the types of normative change in international relations often examined in terms of norm entrepreneurs or cascades. See, for example, Finnemore and Sikkink 1998.

80. Harley 2001, chap. 4.

81. Mukerji 1997. 
territorial states that excludes nonstate units ${ }^{82}$ and also to subjugate peripheral areas by making boundaries linear and exhaustive. For example, the FrenchSpanish boundary in the Pyrenees was finally delineated in the late 1700s, more than a century after the first treaty, but this occurred over the protests of local elites. The centralizing states on either side were able to use the legitimacy of linear boundaries - and the claim to complete authority within those lines-to impose direct control over what had been relatively autonomous communities. ${ }^{83}$ In short, the identities and interests of actors were constituted by a collection of ideas and practices, which then could be used by those actors strategically.

\section{The Territorialization of France}

France offers a particularly useful case for illustrating both the transformation from medieval forms of authority to modern territorial statehood and also the role of mapping in this process. The presence of "France" in the medieval or early modern period often leads modern observers to assume that this polity was identical-in basic character if not exact extent- to the post-Revolutionary state. In fact, the character of this realm was so altered it was virtually unrecognizable: fifteenthcentury France was constituted by a decentralized mix of personal relations of rule and a place-focused form of territoriality, while nineteenth-century France was linearly bounded, homogenously territorial, and centralized. A brief timeline of the relevant political practices and cartographic representations, from the late Middle Ages through the post-Napoleonic restoration, illustrates the complexity of this transformation. Nonpolitically motivated changes in mapmaking offered first the motivation for the territorialization of France and subsequently the tools for implementing changes in political practices.

Even at the end of the Middle Ages, France remained a "mosaic state, made up of many pieces" and held together only loosely by central authority. ${ }^{84}$ The legacy of feudalism meant that much of the king's authority was based on personal ties, or bonds conceptualized as personal ties, between ruler and ruled..$^{85}$ This diverse mix of authority structures is evident in late-medieval interactions, such as the 1435 Congress of Arras. This diplomatic meeting, ostensibly between France, England, and Burgundy, in fact involved a large number of other actors, including independent representatives from Paris and other towns. The negotiations explicitly involved issues of feudal allegiances and authority over a list of towns rather than spatially extensive territories. ${ }^{86}$ The place-focused territorial authority fit with contemporary representations and descriptions of the kingdom. For example, a map

82. Spruyt 1994.

83. Sahlins 1989, 101.

84. Strayer 1970, 53.

85. See Bloch 1961; Finer 1997; Mitteis 1975; and Sahlins 1989, 28.

86. Dickinson 1955. 
of France from a 1460 manuscript depicts the realm as a collection of towns, only generally located geographically ${ }^{87}$ (Figure 6). Medieval French rulers used written inventories to catalogue and manage their realm, yielding "voluminous archives" detailing every jurisdictional right and privilege, territorial and nonterritorial. ${ }^{88}$

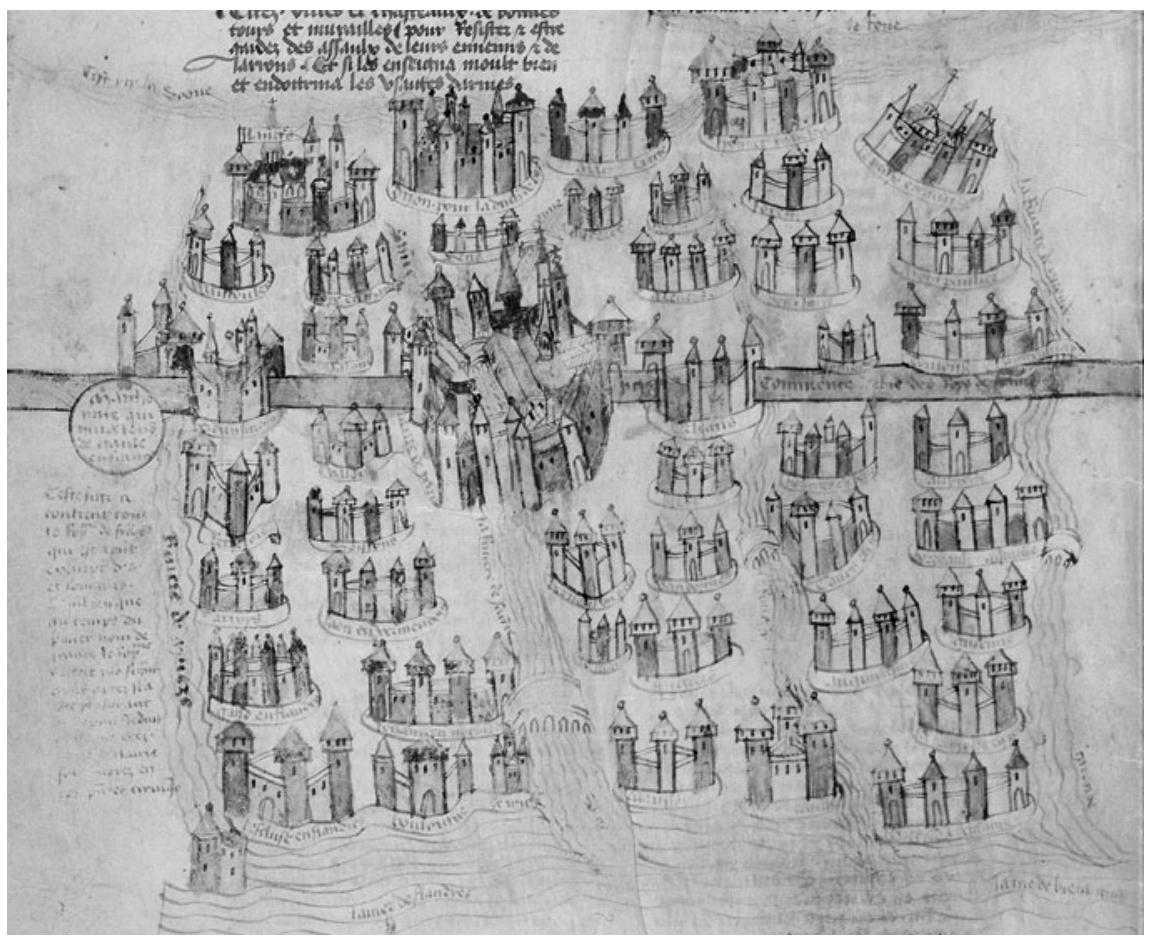

Note: This map, which appears in a manuscript of French history, depicts "all of the realm of France" (Serchuk 2006, 143).

Source: Paris, Bibliothèque nationale de France, Ms Fr 4991 f. 5v. (photograph, all rights reserved: Bibilothèque nationale de France).

FIGURE 6. Manuscript map of France, circa 1460

Beginning in the late fifteenth century, however, the new grid-based printed cartography created a fundamentally new depiction of France. These privately produced maps showed a linearly defined and homogenous color-filled territorial entity. For example, atlas maps of France from the late sixteenth century depict a unified, 
territorially defined area, not the amalgamation of disparate authorities that actually existed (Figure 7). French rulers and political advisors were not ignorant of this new mapmaking, but commercial mapmakers were the first to depict France in the new manner. Rulers therefore collected existing, privately produced maps rather than commissioning official cartographic projects ${ }^{89}$ Late sixteenth-century internal conflict, moreover, disrupted government mapmaking. For example, in the late 1500s, Catherine de' Medici asked Nicolas de Nicolay, a royal geographer, for a "detailed description of the kingdom," but no map of the whole kingdom was produced. Likewise, regional mapmaking was not centralized or standardized, yielding no unified collection of official cartography. ${ }^{90}$

The privately produced maps depicting France as a uniformly territorial entity outpaced political developments during the sixteenth and seventeenth century. For example, in the 1559 Peace of Cateau-Cambrésis, French-Spanish territorial claims were settled in the form of a list of towns: "The King of Spain shall restore to the King of France S. Quentin, Le Catelet and Ham, with their dependencies." ${ }^{91}$ Once again, this demonstrates the persistence of the medieval view of territorial political authority into the sixteenth century.

In the 1600s, French frontiers remained zonal, overlapping, and unclear, with surveying efforts revealing complexities but not leading to linearization in practice (as illustrated by the example of Chastillon). Although the rationalization, or "squaring off," of French frontiers during the reign of Louis XIV (r. 1643-1715), and particularly under his military engineer Vauban, sounds linear, it actually involved securing a series of fortifications in zonal military frontiers. To modern observers who have internalized the rationality of linear boundaries, the very idea of rationalizing frontiers implies linearity. To a military planner of the seventeenth century such as Vauban, however, both the ends and means of rationalization were place-focused (the defense of French cities through increased fortifications in a zonal frontier) rather than imagined in terms of linearly defined spatial expanses. ${ }^{92}$ Political authority within France, moreover, remained decentralized and diverse, as rule remained defined by a variety of feudal, territorial, and jurisdictional titles and claims. ${ }^{93}$ Treaty-making during the seventeenth century also focused on nonlinear territorial divisions and rights. Even the 1659 Treaty of the Pyrenees, which officially introduced the principle of dividing France from Spain along the "natural frontier" of the Pyrenees mountains, operationalized that division using place-focused territoriality: each ruler was assigned control over a series of towns in the frontier region. ${ }^{94}$

89. Buisseret 1992.

90. Pelletier 2007.

91. Russell 1986, 243.

92. On Louis XIV, see Black 1997; Febvre 1973; and Lynn 1999. On Vauban, see Hebbert and Rothrock 1990; and Sahlins 1989.

93. Munck 1990.

94. Sahlins 1989. 


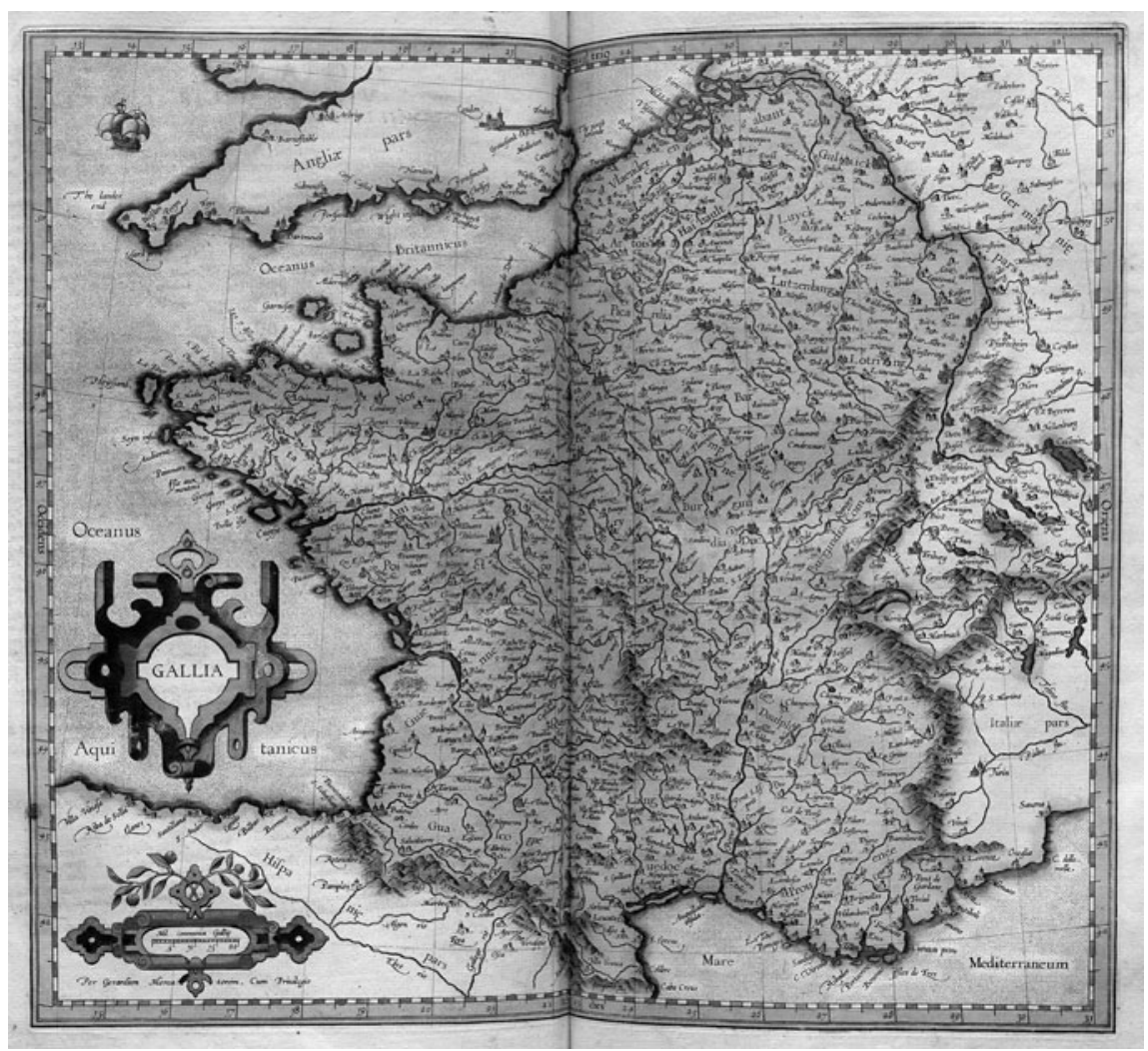

Source: Courtesy of the Lessing J. Rosenwald Collection, Library of Congress.

FIGURE 7. Atlas map of France, Gerhard Mercator, Atlas Cosmographicae, 1595

In the 1620 s and 1630 s, as part an effort to centralize monarchical authority, Richelieu commissioned maps of all of France. Much of this official mapmaking was carried out by Nicolas Sanson, who constructed maps by collecting information from existing sources, rather than from first-hand surveying. ${ }^{95}$ Due to the unsatisfactory character of this "armchair" cartography, in the late 1660s Colbert commissioned a survey-based series of maps of France from Jean-Dominique Cassini, giving rise to a multigenerational mapping project. ${ }^{96}$ This was intended to correct for the inaccuracies and inconsistencies of previous maps by conducting triangulation-based surveys of the entire realm. Although the first complete 
set of maps was not published until 1744 , the project was quickly emulated by other European governments.

This government-sponsored cartography emerged only because privately produced maps had been widely circulated for more than a century. These commercial maps, based on the geometric grid of latitude and longitude, had from the late sixteenth century depicted a world filled with linearly separated territorial entities. It was only later that government actors dedicated resources to conduct surveys and create official, mathematically surveyed maps. Nonpolitical mapping altered ideas about how to make political authority claims, and subsequently those same representational technologies were used for the pursuit of restructured goals of territorial security or expansion.

As cartography became further entrenched as a tool of government, the implementation of the distinctly modern form of territorial authority gradually followed suit. In the second half of the eighteenth century, the rationalization of French frontiers took on its modern form of delimiting, demarcating, and administering linear boundaries. This practical application of linear territoriality followed a growing consensus in the early eighteenth century among political decision makers and advisors that linear boundaries were more rational: "[A] new consciousness of territory ... [became] the concern of the French Ministry of Foreign Affairs, which in the second part of the eighteenth century developed a coherent policy of "establishing and fixing the limits of the kingdom," "involving the explicit use of maps. ${ }^{97}$ Subsequently, French efforts in the 1770s and 1780s included more than a dozen treaties with neighbors, delineating discrete boundaries. ${ }^{98}$ These treaties were explicitly operationalized in terms of territorial exclusivity: properties that straddled the lines had to be divided since territorial settlements no longer simply followed preexisting jurisdictional divisions. ${ }^{99}$ With these agreements, the foreign ministry implemented the cartographic depiction of France as a contiguous, homogenous, and discretely bounded territory.

After 1789, the Revolutionary period saw the further imposition of homogenous territorial authority in France, in particular in the internal reorganization of political administration. The old regime was plagued with internal tariffs, divisions, and administrative confusion. ${ }^{100}$ Ideas had been proposed in the late $1700 \mathrm{~s}$ for more "rational" internal divisions of France, culminating in the 1790 administrative reform aimed toward creating départements of equal geographic area. ${ }^{101}$ This reorganization reflected the notion that territorial sovereignty was homogenous within linear boundaries. In 1814 and 1815, the restoration of the monarchy and rollback of France's territorial expansions did not undo the changes to the character of authority that had been implemented during the preceding decades.

97. See Sahlins 1989, 93; and Konvitz 1987.

98. Black 1999, 125.

99. Sahlins 1989, 95; and Konvitz 1987.

100. Evans 1992, 482-83.

101. Konvitz 1990. 
As with the rest of post-Napoleonic European states, France was explicitly defined as a territorial entity circumscribed by demarcated linear boundaries.

\section{Cartography and Territoriality Outside of Europe}

The state system consolidated in nineteenth-century Europe had a unique form of political authority. Modern statehood is defined exclusively in territorial terms, with units separated exclusively by linear boundaries-no other historical system has been equivalently homogenous and territorial. Ptolemaic cartography is similarly distinct: non-Western cartographic traditions lacked the key combination of coordinate-grid-based mapping and the print-driven production of maps. Thus, in spite of the existence throughout history of both mapping and complex political structures, the unique features of early modern European cartography had an equally unique effect, shaping the distinct characteristics of the modern state system.

Political authority in other settings differed from the modern Western form of territorial exclusivity, in spite of the presence of some political structures reminiscent of modern international relations. Instead, political organization and interaction were built on diverse types of territoriality and nonterritorial authorities, such as the center-focused Roman or Chinese imperial rule or Ottoman control over frontiers as a zonal collection of places. ${ }^{102}$ Similarly, territory in precolonial Africa was organized in a center-out fashion, "conceived of as a series of concentric circles radiating out from the core." ${ }^{103}$ Modern rule defined exclusively by linearly bounded territorial states is the exception-explained in part by the equally exceptional character of modern mapping - rather than a recurring pattern briefly interrupted by medieval complexity. ${ }^{104}$

Non-Western mapping technologies lacked the key features of geometric accuracy, coordinate location, and commercial printing. For example, while ancient Roman mapping used a grid system to divide conquered territory, this grid was not linked to a global coordinate system and thus territory was not homogenized and claimable without direct knowledge. ${ }^{105}$ Traditional Chinese cartography also made occasional use of grids for measuring distances on maps, but these were rare, ad hoc, and not part of a global coordinate system. ${ }^{106}$ Mapping in the Islamic world also diverged from early modern European practices. Even the Ottoman empire-contemporary with and closely linked to early modern Europe-saw little use of maps, with land registers, itineraries, and political claims being almost exclusively in textual form. ${ }^{107}$ Thus the key distinguishing characteristics of mod-

102. See Kratochwil 1986; and Zhang 2001.

103. Herbst 2000, 45.

104. Osiander 2007; Spruyt 1998.

105. Edgerton 1987.

106. Yee 1994.

107. See Harley and Woodward 1992, chaps. 1-14; and Brummett 2007. 
ern mapping-the coordinate-grid structure and massive distribution through printing-uniquely originated in early modern European cartography.

The ideational power of European cartography is further demonstrated by examining the effect it has when introduced into cultures with very different maps and spatial understandings. In the second half of the nineteenth century, for example, Western mapping was introduced wholesale to Siam (Thailand) when a series of reforming monarchs brought in European mapping techniques and mapmakers. ${ }^{108}$ Before the mid-nineteenth century, Siamese mapmaking reflected-and supportedconceptions of political space that lacked the homogenized character of the Ptolemaic grid. Then, over the resistance of Siamese elites, King Rama IV (r. 185168) created Western-style geographic educational and governmental institutions as part of his modernization project. This internal reform process was paralleled by external pressure from encroaching colonial powers who wished to establish clear linear boundaries with still-independent Siam. Frontiers were not the focus of indigenous political authority in the region, however, because power was understood as radiating outward from a center of control into loosely defined frontiers. This clashed with European colonial actors' mental toolkit, structured by modern mapping and exclusively territorial ideas of authority. After the introduction of Western mapping technologies internally, however, indigenous notions of authority were displaced. Siamese elites were then able to use the new ideas both to negotiate more effectively with the British and French and to assert a new form of centralized control over border regions, which had previously been autonomous. In a matter of decades, territorial authority was transformed from loose control over differentiated places, defined from the center outward, to an understanding of territory-based on modern mapping — as homogenous, cartographic, and delineated by clearly defined boundaries.

The case of Siam, though diverging from the European example, nonetheless illustrates the power of mapping to reshape ideas and practices of political authority. Western mapping was introduced from the top, leading to a geometric understanding of political authority based on linear boundaries and homogenous territoriality. Mapping was once again fundamental to the shift to modern statehood.

\section{Conclusion}

Although the use of new cartographic technologies was necessary to the construction and consolidation of the modern state system, this was by no means sufficient: cartography interacted with a number of contingent trends and processes that included not only technological innovations such as printing but also other social, economic, and political developments. Mapping gave sovereign statehood its territorially exclusive character, thereby structuring the effects of other causal 
factors. For example, military pressures driving state centralization and bureaucratization in early modern Europe ${ }^{109}$ could have yielded a number of political forms providing increased extraction and mobilization. It was the hegemony of modern mapping and the resulting understanding of the world as a geometrically divisible surface that channeled this drive toward centralization in the particular direction of creating territorially exclusive, linearly bounded states. Territorial security or expansion, for example, changed from being focused on controlling particular towns to claiming control over linearly defined spaces, thanks to the redefinition of territory itself. This interplay between the ideational effects of cartographic technology and other social and political processes of the period yielded the unique character of modern statehood.

This exclusively territorial basis for political organization was consolidated in the nineteenth century. The post-Napoleonic period saw the elimination of many nonstate forms of organized violence, such as privateering, piracy, and mercenarism. ${ }^{110}$ European colonial empires, though hierarchically organized, continued to be defined territorially, using cartographic tools and linear boundaries (as, for example, at imperial summits such as the 1884-85 Berlin Conference). ${ }^{111}$ In the second half of the twentieth century, however, nonstate and nonterritorial actors have increasingly gained economic or political power. This includes the rise of multinational corporations, international nongovernmental organizations (NGOs), and nonstate violent groups such as terrorist networks. Yet these forms of organization have existed against the normative backdrop of sovereign territorial statehood. Although these other actors have become common, they have always been defined and understood as exceptions to the norm of territorially exclusive statehood. Similarly, the effective failure of state power or authority is understood as just that, as a "failed state," and not in terms of a new or different positively defined authority structure.

Nonetheless, interactions between representational technologies, spatial ideas, and political practices and outcomes are possibly occurring today. Since mapping played a key role in constituting the foundation of modern sovereign statehood (and in particular its territorially exclusive character), contemporary changes in cartographic technologies could undermine or transform that foundation. Today's new digital cartographies present at least the possibility of depicting more complex nonstate forms of political authority. This offers a new focus for the study of globalization, ${ }^{112}$ the information technology (IT) revolution, ${ }^{113}$ and possible contemporary changes in political territoriality. ${ }^{114}$ While the IT revolution may have

109. Noted in particular by Tilly 1992; and Downing 1992.

110. Thomson 1994.

111. Bassett 1994.

112. Globalization is addressed in a huge body of work, reviewed most prominently by Held et al. 1999.

113. Castells 1996 has probably been the most influential study on the IT revolution's political effects.

114. Such as in the question of tendencies toward deterritorialization or reterritorialization. See, for example, Brenner 1999. 
direct effects on political representations, ideas, and practices, focusing on digital cartography highlights one particular development within the larger category of interactions between technologies and political structures

Cartographic technologies are being transformed by computerization and networking. The increasingly widespread use of Web-based mapping tools, virtual globes (such as Google Earth), geographic information systems (GIS), and even personal mapping and navigation technologies using the global positioning system (GPS) are changing the ways in which maps are created, distributed, and used. ${ }^{115}$ Particularly reminiscent of the early modern period is the way in which these technologies are again outside the exclusive control of political actorsoverturning the dominant position of official government cartography during the nineteenth and twentieth centuries. This means that, once again, nonpolitical motivations may lead to new depictions, potentially changing how actors negotiate over space, make political claims, or conceive of political authority or community.

In the short term, new tools may be put to use in interactions and negotiations, enabling new bargains over difficult divisions. The complexity of mapping and displaying information about spaces other than land surfaces-such as oceanic or underground resources - has made the resolution and enforcement of agreements difficult. Yet with technologies for accurately measuring and displaying detailed information increasingly affordable and available, divisions may be more easily effected. These techniques include both three-dimensional mapping and maps that move to represent the passage of time.

If nonlinear divisions can be mapped, some previously indivisible spaces or resources may become divisible in new ways. ${ }^{116}$ So far, however, new tools have been used mostly for traditional goals of delineating discrete boundaries. At Dayton in 1995, for instance, GIS and other digital mappings were used with only limited results: the technologies were still low-resolution and negotiators resisted eliminating their paper maps. ${ }^{117}$ Although the technological possibility of visualizing more complex or layered political authorities exists, there is no guarantee that actors will adopt such ideas.

Moreover, the technological trend toward increasing accuracy and reduced cost in location-finding and mapping may actually destabilize existing settlements and make some agreements more difficult. For example, the ability of almost anyone with a hand-held GPS device to determine exact locations may reveal inconsistencies in existing boundaries and thus remove political "wriggle room" for negotiation. During the early modern period, many divisions were negotiated in spite of uncertainty regarding the actual divisions on the ground - an accepted ambiguity that made these resolutions easier, as it allowed complex local solutions to emerge. Today, as the technological ability to find one's position with pin-point accuracy

115. Discussions of these issues from geography include Miller 2006; and Crampton 2009.

116. See Goddard 2006; and Hassner 2003.

117. Johnson 1999. 
and to reference it to detailed maps is increasingly available, the recourse to ambiguous but workable divisions is becoming less available, possibly further entrenching territorial disputes. ${ }^{118}$

While predigital mapmaking was based on standardization and the abstraction of human space onto the Ptolemaic grid, computerized map production and distribution might open up those constraints and undermine the homogenization of space. This could restructure territoriality and give advocates of new authority types the representational tools required to overcome the image of the political world as a color-coded, boundary-filled map. With the digital revolution, maps are no longer predetermined objects, created only in large institutional settings and with only one set of characteristics. Now cartography is more "open-source," and maps are created and altered by users themselves. ${ }^{119}$ These flexible digital maps have the potential to display more complex representations of space, and political authority or community within it. ${ }^{120}$ Therefore, with the wider availability of more participatory forms of mapmaking, existing ideas of authority and political organization could be undermined, or replaced. This is possible with both highly technical GIS applications as well as with popular Web-based maps: both Google Maps and Google Earth, for example, allow users to create and distribute additional information layers not included in the initial base maps. ${ }^{121}$

Yet the participatory and emancipatory potential of these technologies can easily be overstated. Although users can add content and change how content is viewed, these tools do not appear out of thin air but are created by technical experts with their own ideas and norms, and perhaps political agendas. Even the relatively open Google Earth has default settings, as does any software. Thus, both the maps' original characteristics and the outer bounds of what can be changed on them are determined by trained experts inside institutions, not by end-users.

The most fundamental structure of these online mapping tools is their basis in the coordinate grid. GIS, GPS applications, and online digital mappings all start with the geometric understanding of space, defined by coordinate location. Even replacing abstract map images with satellite photography merely moves one step closer to the Enlightenment ideal of a map reflecting reality as a perfect mirror. Therefore, while the tendency of printed maps toward linear division and homogenous color-coding may be undermined, the underlying understanding of space remains the same.

Nevertheless, the expansion of cartographic possibilities today is a potential source of change in political ideas and practices, just as the new Ptolemaic techniques and their widespread adoption transformed political authority in early modern Europe. In fact, a key similarity exists: the absence of centralized control over

118. Hassner 2006/2007.

119. Crampton and Krygier 2006, 15.

120. Including notions such as "world-city networks" or the "space of flows." See Taylor 2005; and Castells 1996.

121. Miller 2006. 
cartography by political interests. Just as in the sixteenth and seventeenth centuries, today most of the new forms of mapping are being pursued by nongovernmental actors, even if governments are working in parallel. ${ }^{122}$ This is different from most of the nineteenth and twentieth centuries, when maps were predominantly created by, or for, states. Today nonpolitical mapmakers are at the forefront, and thus we might see a new transformative process driven by representations in these widely distributed, and increasingly democratized, mapping technologies.

The modern state system was founded on a collection of representations and narratives about the world, a major component of which was supplied (and continues to be supplied) by maps. The question remains, then, whether new technologies and practices will strengthen, transform, or replace those foundations. Focusing our attention on the intersection between technological changes, ideas of legitimate authority, and political practices offers the best means of approaching this fundamental issue.

\section{References}

Adler, Emanuel. 2005. Communitarian International Relations: The Epistemic Foundations of International Relations. New York: Routledge.

Akerman, James R. 1984. Cartography and the Emergence of Territorial States in Western Europe. In Proceedings of the Tenth Annual Meeting of the Western Society for French History, edited by John F. Sweets, 138-54. Lawrence: University of Kansas Press.

- 1995. The Structuring of Political Territory in Early Printed Atlases. Imago Mundi 47:138-54.

Anderson, Perry. 1974. Lineages of the Absolutist State. London: New Left Books.

Archer, Margaret S. 1995. Realist Social Theory: The Morphogenetic Approach. Cambridge: Cambridge University Press.

Bassett, Thomas J. 1994. Cartography and Empire Building in Nineteenth-Century West Africa. Geographical Review 84 (3):316-35.

Biggs, Michael. 1999. Putting the State on the Map: Cartography, Territory, and European State Formation. Comparative Studies in Society and History 41 (2):374-405.

Black, Jeremy. 1997. Maps and Politics. Chicago: University of Chicago Press. . 1999. From Louis XIV to Napoleon: The Fate of a Great Power. London: UCL Press.

Bloch, Marc. 1961. Feudal Society. 2 vols. Translated by L. A. Manyon. Chicago: University of Chicago Press.

Branch, Jordan. 2009. The Expansion of Europe or Colonial Reflection? On the Extra-European Origins of the Modern International System. Paper presented at the 50th Annual Meeting of the International Studies Association, February, New York.

Brenner, Neil. 1999. Beyond State-Centrism? Space, Territoriality, and Geographic Scale in Globalization Studies. Theory and Society 28 (1):39-78.

Brotton, Jerry. 1997. Trading Territories: Mapping the Early Modern World. Ithaca, N.Y.: Cornell University Press.

Brummett, Palmira. 2007. Imagining the Early Modern Ottoman Space, from World History to Piri Reis. In The Early Modern Ottomans: Remapping the Empire, edited by Virginia H. Aksan and Daniel Goffman, 15-58. Cambridge: Cambridge University Press. 
Buisseret, David. 1984. The Cartographic Definition of France's Eastern Boundary in the Early Seventeenth Century. Imago Mundi 36 (1):72-80.

. 1992. Monarchs, Ministers, and Maps: The Emergence of Cartography as a Tool of Government in Early Modern Europe. Chicago: University of Chicago Press.

Bull, Hedley. 1977. The Anarchical Society. New York: Columbia University Press.

Buzan, Barry, and Richard Little. 2000. International Systems in World History: Remaking the Study of International Relations. Oxford, England: Oxford University Press.

Campbell, Tony. 1987. Portolan Charts from the Late Thirteenth Century to 1500. In The History of Cartography. Vol.1, Cartography in Prehistoric, Ancient, and Medieval Europe and the Mediterranean, edited by J.B. Harley and David Woodward, 371-463. Chicago: University of Chicago Press.

Carlsnaes, Walter. 1992. The Agency-Structure Problem in Foreign Policy Analysis. International Studies Quarterly 36 (3):245-70.

Castells, Manuel. 1996. The Rise of the Network Society. Vol. I, The Information Age: Economy, Society, and Culture. Oxford, England: Blackwell.

Cosgrove, Denis. 2001. Apollo's Eye: A Cartographic Genealogy of the Earth in the Western Imagination. Baltimore, Md.: Johns Hopkins University Press.

Crampton, Jeremy W. 2009. Cartography: Maps 2.0. Progress in Human Geography 33 (1):91-100.

Crampton, Jeremy W., and John Krygier. 2006. An Introduction to Critical Cartography. ACME: An International E-Journal for Critical Geographies 4 (1):11-33.

Dickinson, Joycelyne Gledhill. 1955. The Congress of Arras, 1435: A Study in Medieval Diplomacy. Oxford, England: Clarendon Press.

Doty, Roxanne Lynn. 1997. Aporia: A Critical Exploration of the Agent-Structure Problematique in International Relations Theory. European Journal of International Relations 3 (3):365-92.

Downing, Brian M. 1992. The Military Revolution and Political Change: Origins of Democracy and Autocracy in Early Modern Europe. Princeton, N.J.: Princeton University Press.

Edgerton, Samuel Y., Jr. 1987. From Mental Matrix to Mappamundi to Christian Empire: The Heritage of Ptolemaic Cartography in the Renaissance. In Art and Cartography: Six Historical Essays, edited by David Woodward, 10-50. Chicago: University of Chicago Press.

Edson, Evelyn. 1997. Mapping Time and Space: How Medieval Mapmakers Viewed Their World. London: British Library.

Ehrensvärd, Ulla. 1987. Color in Cartography: A Historical Survey. In Art and Cartography: Six Historical Essays, edited by David Woodward, 123-46. Chicago: University of Chicago Press.

Eisenstein, Elizabeth L. 1979. The Printing Press as an Agent of Change. 2 vols. Cambridge: Cambridge University Press.

Evans, R. J. W. 1992. Essay and Reflection: Frontiers and National Identities in Central Europe. International History Review 14 (3):480-502.

Febvre, Lucien. 1973. Frontière: The Word and the Concept. In A New Kind of History: From the Writings of Febvre. Translated by K. Folca; edited by Peter Burke, 208-18. London: Routledge and Kegan Paul.

Finer, Samuel E. 1997. The History of Government from the Earliest Times. 3 vols. Oxford, England: Oxford University Press.

Finnemore, Martha, and Kathryn Sikkink. 1998. International Norm Dynamics and Political Change. International Organization 52 (4):887-917.

Fischer, Markus. 1992. Feudal Europe, 800-1300: Communal Discourse and Conflictual Practices. International Organization 46 (2):427-66.

Ganshof, François L. 1970. The Middle Ages: A History of International Relations. Translated by Rémy Inglis Hall. New York: Harper and Row.

Giddens, Anthony. 1984. The Constitution of Society: Outline of the Theory of Structuration. Oxford, England: Polity Press.

Gilpin, Robert. 1981. War and Change in World Politics. Cambridge: Cambridge University Press.

Goddard, Stacie E. 2006. Uncommon Ground: Indivisible Territory and the Politics of Legitimacy. International Organization 60 (1):35-68. 
Goodchild, Michael F. 2007. Citizens as Sensors: The World of Volunteered Geography. GeoJournal 69 (4):211-21.

Gorski, Philip S. 2003. The Disciplinary Revolution: Calvinism and the Rise of the State in Early Modern Europe. Chicago: University of Chicago Press.

Grafton, Anthony. 1992. New Worlds, Ancient Texts: The Power of Tradition and the Shock of Discovery. Cambridge, Mass.: Harvard University Press.

Hall, Rodney Bruce. 1999. National Collective Identity: Social Constructs and International Systems. New York: Columbia University Press.

Hall, Rodney Bruce, and Friedrich V. Kratochwil. 1993. Medieval Tales: Neorealist 'Science' and the Abuse of History. International Organization 47 (3):479-91.

Harley, J. B. 2001. The New Nature of Maps: Essays in the History of Cartography, edited by Paul Laxton. Baltimore, Md.: Johns Hopkins University Press.

Harley, J. B., and David Woodward. 1987. The History of Cartography. Vol. 1, Cartography in Prehistoric, Ancient, and Medieval Europe and the Mediterranean. Chicago: University of Chicago Press.

- 1992. The History of Cartography, Vol. 2, Book 1, Cartography in the Traditional Islamic and South Asian Societies. Chicago: University of Chicago Press.

Hassner, Ron E. 2003. 'To Halve and to Hold': Conflicts over Sacred Space and the Problem of Indivisibility. Security Studies 12 (4):1-33.

- 2006/2007. The Path to Intractability: Time and the Entrenchment of Territorial Disputes. International Security 31 (3):107-38.

Hebbert, F. J., and G. A. Rothrock. 1990. Soldier of France: Sebastien Le Prestre de Vauban, 16331707. New York: Peter Lang.

Held, David, Anthony McGrew, David Goldblatt, and Jonathan Perraton. 1999. Global Transformations: Politics, Economics, Culture. Stanford, Calif.: Stanford University Press.

Herbst, Jeffrey. 2000. States and Power in Africa: Comparative Lessons in Authority and Control. Princeton, N.J.: Princeton University Press.

Holzgrefe, J. L. 1989. The Origins of Modern International Relations Theory. Review of International Studies 15 (1):11-26.

Israel, Fred L. 1967. Major Peace Treaties of Modern History, 1648-1967. Vol. I. Philadelphia: Chelsea House.

Johnson, Richard G. 1999. Negotiating the Dayton Peace Accords Through Digital Maps. USIP Virtual Diplomacy Report, 25 February 1999.

Karrow, Robert. 2007. Centers of Map Publishing in Europe, 1472-1600. In The History of Cartography. Vol. 3, Cartography in the European Renaissance, edited by David Woodward, 611-21. Chicago: University of Chicago Press.

King, Geoff. 1996. Mapping Reality: An Exploration of Cultural Cartographies. London: MacMillan.

Klinghoffer, Arthur Jay. 2006. The Power of Projections: How Maps Reflect Global Politics and History. Westport, Conn.: Praeger.

Koeman, Cornelis. 1970. Joan Blaeu and His Grand Atlas. Amsterdam: Theatrum Orbis Terrarum.

Konvitz, Josef W. 1987. Cartography in France, 1660-1848: Science, Engineering, and Statecraft. Chicago: University of Chicago Press.

- 1990. The Nation-State, Paris and Cartography in Eighteenth- and Nineteenth-Century France. Journal of Historical Geography 16 (1):3-16.

Krasner, Stephen D. 1993. Westphalia and All That. In Ideas and Foreign Policy: Beliefs, Institutions, and Political Change, edited by Judith Goldstein and Robert Keohane, 235-64. Ithaca, N.Y.: Cornell University Press.

2001. Rethinking the Sovereign State Model. Review of International Studies 27 (5):17-42.

Kratochwil, Friedrich. 1986. Of Systems, Boundaries, and Territoriality: An Inquiry into the Formation of the State System. World Politics 39 (1):27-52.

- 1989. Rules, Norms, and Decisions: On the Conditions of Practical and Legal Reasoning in International Relations and Domestic Affairs. Cambridge: Cambridge University Press.

Lake, David A. 2003. The New Sovereignty in International Relations. International Studies Review 5 (3):303-23. 
2009. Hierarchy in International Relations. Ithaca, N.Y.: Cornell University Press.

Lefebvre, Henri. 1991 [1974]. The Production of Space. Translated by Donald Nicholson-Smith. Cambridge, Mass.: Blackwell.

Lynn, John A. 1999. The Wars of Louis XIV, 1667-1714. London: Longman.

Mahoney, James. 1999. Nominal, Ordinal and Narrative Appraisal in Macrocausal Analysis. American Journal of Sociology 104 (4):1154-96.

March, James G., and Johan P. Olsen. 1998. The Institutional Dynamics of International Political Orders. International Organization 52 (4):943-69.

McNeill, William H. 1982. The Pursuit of Power: Technology, Armed Force, and Society Since A.D. 1000. Chicago: University of Chicago Press.

Miller, Christopher C. 2006. A Beast in the Field: The Google Maps Mashups as GIS/2. Cartographica 41 (3):187-99.

Milner, Helen. 1991. The Assumption of Anarchy in International Relations Theory: A Critique. Review of International Studies 17 (1):67-85.

Mitteis, Heinrich. 1975. The State in the Middle Ages: A Comparative Constitutional History of Feudal Europe. Amsterdam: North-Holland.

Mukerji, Chandra. 1997. Territorial Ambitions and the Gardens of Versailles. Cambridge: Cambridge University Press.

- 2006. Printing, Cartography, and Conceptions of Place in Renaissance Europe. Media, Culture \& Society 28 (5):651-69.

Munck, Thomas. 1990. Seventeenth Century Europe: State, Conflict and the Social Order in Europe, 1598-1700. New York: St. Martin's.

Mundy, Barbara E. 1996. The Mapping of New Spain: Indigenous Cartography and the Maps of the Relaciones Geográficas. Chicago: University of Chicago Press.

Neocleous, Mark. 2003. Off the Map: On Violence and Cartography. European Journal of Social Theory 6 (4):409-25.

Osiander, Andreas. 1994. The States System of Europe, 1640-1990: Peacemaking and the Conditions of International Stability. Oxford, England: Clarendon Press.

- 2001. Sovereignty, International Relations, and the Westphalian Myth. International Organization 55 (2):251-87.

-2007. Before the State: Systemic Political Change in the West from the Greeks to the French Revolution. Oxford, England: Oxford University Press.

Pedley, Mary Sponberg. 1992. Bel et Utile: The Work of the Robert de Vaugondy Family of Mapmakers. Herts, England: Map Collector Publications.

Pelletier, Monique. 1998. Cartography and Power in France During the Seventeenth and Eighteenth Centuries. Cartographica 35 (3/4):41-53.

2007. National and Regional Mapping in France to About 1650. In The History of Cartography. Vol. 3, Cartography in the European Renaissance, edited by David Woodward, 1480-1503. Chicago: University of Chicago Press.

Philpott, Daniel. 2001. Revolutions in Sovereignty: How Ideas Shaped Modern International Relations. Princeton, N.J.: Princeton University Press.

Pickles, John. 2004. A History of Spaces: Cartographic Reason, Mapping, and the Geo-coded World. New York: Routledge.

Reus-Smit, Christian. 1999. The Moral Purpose of the State: Culture, Social Identity, and Institutional Rationality in International Relations. Princeton, N.J.: Princeton University Press.

Revel, Jacques. 1991. Knowledge of the Territory. Science in Context 4 (1):133-61.

Rosenberg, Justin. 1994. The Empire of Civil Society: A Critique of the Realist Theory of International Relations. London: Verso.

Ruggie, John G. 1983. Continuity and Transformation in the World Polity: Toward a Neorealist Synthesis. World Politics 35 (2):261-85.

- 1993. Territoriality and Beyond: Problematizing Modernity in International Relations. International Organization 47 (1):139-74.

Russell, Joycelyne G. 1986. Peacemaking in the Renaissance. London: Duckworth. 
Sack, Robert David. 1986. Human Territoriality: Its Theory and History. Cambridge: Cambridge University Press.

Sahlins, Peter. 1989. Boundaries: The Making of France and Spain in the Pyrenees. Berkeley: University of California Press.

- 1990. Natural Frontiers Revisited: France's Boundaries Since the Seventeenth Century. American Historical Review 95 (5):1423-51.

Schroeder, Paul W. 1994. The Transformation of European Politics: 1763-1848. Oxford, England: Clarendon Press.

Schulz, Juergen. 1987. Maps as Metaphors: Mural Map Cycles of the Italian Renaissance. In Art and Cartography: Six Historical Essays, edited by David Woodward, 97-122. Chicago: University of Chicago Press.

Serchuk, Camille. 2006. Picturing France in the Fifteenth Century: The Map in BNF MS Fr. 4991. Imago Mundi 58 (2):133-49.

Skinner, Quentin. 1978. The Foundations of Modern Political Thought. 2 vols. Cambridge: Cambridge University Press.

Spruyt, Hendrik. 1994. The Sovereign State and Its Competitors. Princeton, N.J.: Princeton University Press.

- 1998. Historical Sociology and Systems Theory in International Relations. Review of International Political Economy 5 (2):340-53.

Steinberg, Philip E. 2005. Insularity, Sovereignty, and Statehood: The Representation of Islands on Portolan Charts and the Construction of the Territorial State. Geografiska Annaler 87 (4):253-65.

Strandsbjerg, Jeppe. 2008. The Cartographic Production of Territorial Space: Mapping and State Formation in Early Modern Denmark. Geopolitics 13 (2):335-58.

Strayer, Joseph R. 1970. On the Medieval Origins of the Modern State. Princeton, N.J.: Princeton University Press.

Taylor, Peter J. 1995. Beyond Containers: Internationality, Interstateness, Interterritoriality. Progress in Human Geography 19 (1):1-15.

. 2005. New Political Geographies: Global Civil Society and Global Governance through World City Networks. Political Geography 24 (6):703-30.

Teschke, Benno. 1998. Geopolitical Relations in the European Middle Ages: History and Theory. International Organization 52 (2):325-58.

Thomson, Janice E. 1994. Mercenaries, Pirates, and Sovereigns: State-Building and Extraterritorial Violence in Early Modern Europe. Princeton, N.J.: Princeton University Press.

Thongchai Winichakul. 1994. Siam Mapped: A History of the Geo-Body of a Nation. Honolulu: University o Hawai'i Press.

Tilly, Charles. 1992. Coercion, Capital, and European States, AD 990-1992. London: Blackwell.

Wallerstein, Immanuel. 1974: The Modern World-System I: Capitalist Agriculture and the Origins of the European World-Economy in the Sixteenth Century. London: Academic Press.

Waltz, Kenneth N. 1979. Theory of International Politics. Reading, Mass.: Addison-Wesley.

Wendt, Alexander. 1987. The Agent-Structure Problem in International Relations Theory. International Organization 41 (3):335-70.

- 1999. Social Theory of International Politics. Cambridge: Cambridge University Press.

Wight, Colin. 1999. They Shoot Dead Horses Don't They? Locating Agency in the Agent-Structure Problematique. European Journal of International Relations 5 (1):109-42.

Wight, Martin. 1977. Systems of States. Leicester, England: Leicester University Press.

Wood, Denis. 1992. The Power of Maps. New York: Guilford Press.

Woodward, David. 2007. The History of Cartography. Vol. 3, Cartography in the European Renaissance. Chicago: University of Chicago Press.

Yee, Cordell D. K. 1994. Chinese Maps in Political Culture. In The History of Cartography. Vol. 2, Book 2, Cartography in the Traditional East and Southeast Asian Societies, edited by J.B. Harley and David Woodward, 71-95. Chicago: University of Chicago Press.

Zhang, Yongjin. 2001. System, Empire and State in Chinese International Relations. Review of International Studies 27 (5):43-63. 